\title{
INTEGRATION MANAGEMENT - ADAPTIVE LIFE CYCLE APPROACH IN SOLAR PLANT CONSTRUCTION PROJECT - EXPERIENCE REPORT
}

\section{ORIGINAL ARTICLE}

MOREIRA JÚNIOR, Apparício Ramalho ${ }^{1}$

MOREIRA JÚNIOR, Apparício Ramalho. Integration management - adaptive life cycle approach in solar plant construction project - experience report. Revista Científica Multidisciplinar Núcleo do Conhecimento. Year. 06, Ed. 09, Vol. 01, pp. 5892. September 2021. ISSN: 2448-0959, Access Link:

https://www.nucleodoconhecimento.com.br/engineering-mechanicalengineering/integration-management, DOI:

10.32749/nucleodoconhecimento.com.br/engineering-mechanicalengineering/integration-management

\section{ABSTRACT}

The objective of this experience report was to present the solutions used in the Management Process of the Construction and Assembly project of a Solar Photovoltaic Plant in utilitarian scale, in complex, uncertain and conflicting contexts. As a leading issue, it is intended to demonstrate that new approaches adopted in the project reported here - distinct from the traditional model and practices - allowed the mitigation of the main problems common to construction projects, including divergences between executive project and field activity, delays in delivery and deadlines initially contracted, and consequent additional expenses to the base budget. As a methodology, its theoretical foundation was based on bibliographic survey, addressing aspects such as: project management and life cycle of them, integration between the various processes and stakeholders, and Solar Energy on a utilitarian scale, in the scope of construction. This experience report aimed to discuss and

\footnotetext{
${ }^{1}$ Post-Graduate Lato Sensu - MBA in Project Management - Fundação Getúlio Vargas (FGV); Bachelor’ s in

Access Link: https://www.nucleodoconhecimento.com.br/engineering-mechanicalengineering/integration-management
} 
mechanical engineering - Federal University of Pernambuco. ORCID: https://orcid.org/0000-0002-6506-9768 RC: 99138

Access Link: https://www.nucleodoconhecimento.com.br/engineering-mechanicalengineering/integration-management 
demonstrate the approach used in the Guañizuil II A project, located in Argentina, in which agility, flexibility and innovation resulted in the mitigation of delays and additional costs, the achievement of notable records and the development of practical alternatives that can be applied to other construction projects. It is concluded that engineering projects, in their executive phase, need to be aligned with reality in the field, where an adaptive approach can bring positive gains and impacts throughout the life cycle.

Keywords: Project Management, Construction and Assembly, Photovoltaic Solar Power Plants, Project Lifecycle, PMBOK®.

\section{INTRODUCTION}

It is common in much of the literature related to engineering projects the idea that "rework, the delay in the delivery of works and the extrapolation of the budget" (SOUSA et al., 2020, p. 1), is a problem for the construction industry. To achieve the reliability and safety necessary for a project, Sousa et al. (2020, p. 2, referring to LEHTIRANTA, 2014) argue that "the set of procedures, criteria and guidelines is called the Management System, whose implementation should be based on a clear strategy".

According to the experience reported here, aspects such as competitiveness, quality and reliability are so fundamental that they take the different professionals to the maximum care throughout the duration of a process. Since these aspects interfere in the application of generic project management models and considering that the Construction sector requires "numerous parallel services", it is highlighted that all projects in this area require planning, projections, budget, schedule, management, execution and quality control.

In other words, in view of some particularities in the different works, their management leads to the subdivision of such services into smaller projects, which allows the managing engineer to make the most punctual decisions to solve the issues that arise during the realization of the project itself, deciding more simply, and that are in RC: 99138 
accordance with the scope of the management system and management as a whole (SOUSA et al., 2020).

It is common that among the aspects that characterize civil construction projects are listed "delays, material losses, delay in decision-making of owners and project errors" (TAFAZZOLI and SHRESTHA, 2017, p. 611). This study refers specifically to works in the United States; however, these are issues confirmed by other sources of research, as well as in the empiricism that permeates the experiences of engineering, thus requiring specialized professionals to identify the improvements to be adopted, which allow the mitigation of these problems.

Also from the perspective of this experience, the beginning of the feasibility of the implementation of a solar project on a utilitarian scale happens through the prospection of basic location information so that the solar incidence of the region is evaluated, and with this, its power generation capacity. From this information, should also be analyzed the supplies, labor and equipment necessary for the installation of this type of project, in addition to the best financial structure available to support such an undertaking.

In addition, a variety of information is needed to elaborate the technical drawings and specify the materials that will define the way the unit is constructed. In this sense, the information produced in initial tests or similar projects should be used, which allows the verification of the conditions of the terrain, such as: a) mechanical resistance of the soil to withstand the various loads produced by the mechanical structures (trackers); b) pullout force because of the effect of wind, temperature effect on the structures; c) chemical analysis of the soil to verify the effects of corrosion, among other information contained in the geological reports produced during the studies.

The stage known as the Basic Project, "Planning, Programming and Budget",is effectively the beginning of the project, and consists, as the name suggests, in: planning, programming and budgeting. The next phase refers to the detailing of the

RC: 99138

Access Link: https://www.nucleodoconhecimento.com.br/engineering-mechanicalengineering/integration-management 
Execution Project, where good engineering practices are applied together with the experience, experience and lessons learned in other projects.

Complementary logistics activities are also established regarding the availability of materials fromtrackers, drillingequipment,pile-driving machines, purchaseof solar panels and batteries, in addition to hiring contractors for earthworks, assembly, electrical connections and substations, as well as work support activities, which need to be planned and executed by the Project Manager, from all executive data.

With regard to renewable energy projects, there are many difficulties to overcome for the generation of this type of energy. Among the difficulties in construction, we highlight those that can be grouped into three significant gaps: 1) Project divergence; 2) Inefficient management; 3) Shortage of experienced workforce.

These gaps, which will be detailed throughout this article, were duly corrected by applying an adaptive approach in project management and constructibility and assembly of structures during the implementation of the project to build a solar park on a utilitarian scale of $117 \mathrm{MW}$ - a project that was called Guañizuil, 2A, and carried out during 2019.

Since inconsistencies in construction drawings arise in the project in the field, when geological studies and preliminary analyses are consulted, and above all, the technical needs for theassembly of the structures (trackers), a set that can cause rework, it was found that the implementation of the project in question, located in the region of the Andes, would require a specific approach, risks of strong impacts and distortions due to the altitude of its location.

To mitigate the gaps mentioned above, the knowledge of the PMBOK Guide® were important, through good practices for project management contained therein.

\section{PROJECT MANAGEMENT APPLIED TO CONSTRUCTION}

RC: 99138

Access Link: https://www.nucleodoconhecimento.com.br/engineering-mechanicalengineering/integration-management 


\subsection{PROJECT MANAGEMENT}

The good management of the resources available in the different organizations has become, over time, the fundamental part for companies to be more competitive and thus progress, which implies decisions for the adoption of various actions to be implemented consistently and constantly.

Thus, it is worth noting at first that Siqueira; Menezes and Oliveira $(2018$, p. 2) refer Maximiano (2006, p. 363), to define which projects are:

Atividades temporárias, com começo, meio e fim programados, que têm como objetivo fornecer um produto singular. O resultado de um projeto pode ser um produto físico, como uma nova fábrica, um conceito, como um novo sistema de informações, ou um evento, como os jogos olímpicos. Muitos projetos são combinações desses três tipos de produtos.

Gomes et al. (2020, p. 107) argue that projects constitute "a single event with a defined start and end period", Farias (2018, p. 13) explains that the concept of success in projects was changing, since at first, managers evaluated success from the technical perspective, as well as the adequacy or lack of adequacy of the project product and cost control.

Farias (2018) also reports the definition elaborated by Vargas $(2009$, p. 14) on a successful project, and it is up to him: "[...] be completed within the expected time, within budget, reaching the desired quality, using the resources efficiently, with minimal changes in scope and having been accepted without restrictions by the client".

The fact is that, at a given moment, succeeding in a project began to represent, in addition to the other aspects, the fulfillment of deadlines, the adequate control of costs and also the offer of something at a quality level compatible with what was agreed from the beginning. This was an internal evaluation among managers, but there was an aspect of great relevance that was not yet taken into account: customer satisfaction (KERZNER, 2006, p. 40, apud FARIAS, 2018).

RC: 99138

Access Link: https://www.nucleodoconhecimento.com.br/engineering-mechanicalengineering/integration-management 
In turn, Rabechini Jr. and Pessôa (2005, p. 34) teach that it is only through the development of "competencies in various aspects that maturity in project management can be developed, since this process requires time and is still reflected in all sectors of the organization". These authors report Pinto (1983) and Sleven (1998) to explain the existence of four criteria, in Project Management, to highlight: "time, cost, effectiveness and customer satisfaction".

It is these criteria that allow a project to be considered successful by experts, based on some factors: mission, management support, plan, consultant client, personal issues, technical issues, customer acceptance, communication, monitoring and conciliation.

\subsection{PROJECT MANAGEMENT IN CONSTRUCTION}

From the perspective of this report, the Construction segment is a production sector for which the literature criticized the lack of a manual to be followed. Each project has specific characteristics, which are inherent to the value of the investment, the interests and requirements of its investors, the location for the realization of the project and its local specificities, in addition to the needs of specialized personnel at each stage of the engineering project.

In the opinion of Sousa et al. (2020, p.1), the engineering industry lacks "management systems and consolidated tools and techniques to assist in decision making", and there are still missing rules and targets previously defined in the preparation of budgets and schedules.

In this sense, much of the literature referred to the lack of a comprehensive methodology that results in the practices of Civil Construction, which understands the project from the beginning and until its end.

RC: 99138

Access Link: https://www.nucleodoconhecimento.com.br/engineering-mechanicalengineering/integration-management 
Xavier (2012, p. 1) highlights the definition of methodology conferred by Charvat (2003):

\begin{abstract}
uma metodologia é um conjunto de orientações e princípios que podem ser adaptados e aplicados em uma situação específica. Em ambiente de projetos essa orientação é uma lista de coisas a fazer. Uma metodologia pode também ter uma abordagem específica, modelos, formulários e também check lists, usados durante o ciclo de vida do projeto.
\end{abstract}

In this regard, Xavier (2012, p. 1) reports that among the results of the "Project Management Benchmarking Study", 2010, it was confirmed the lack of a national or international project management methodology, which is effective and that can be used in general by the Construction area.

Tafazzoli and Shrestha (2017, p. 611), complement the statements of Xavier (2012) and Souza et al. (2020), stating that the delay in construction projects is a global problem, causing considerable losses for many economies. The authors present a national survey conducted in the USA, with experienced experts from the construction industry, evaluating the relative criticality of the causes of delay. It was found that due to the complexities in the standardization of construction projects, efforts to mitigate the risks of delay were not adequately successful.

In this perspective, the $\mathrm{PMBOK} \circledast$ guide, which is a guide of good practices, has established itself over time as a basis for application in Project Management in different market areas. However, as will be seen in more detail in a specific and sequential subitem to this, at a given time it was necessary to create a smaller guide, which would include the Engineering industry. With this initiative, the PMI allowed the managers of this segment to take specific good practices, however, with internal methods, according to the work under way.

\title{
2.3 PROJECT MANAGEMENT INSTITUTE (PMI) AND THE PMBOK® GUIDE
}

RC: 99138

Access Link: https://www.nucleodoconhecimento.com.br/engineering-mechanicalengineering/integration-management 
The Project Management Institute (PMI) was established in 1969 in Pennsylvania, United States. It is a non-profit institution, focused on good practices in project management of different sectors of the economy (PMI, 2013).

From a group of professionals who were part of the PMI, the PMBOK Guide was created in 1990® work developed to "guide, standardize and disseminate the most efficient practices in projects in their different stages, already tested and approved around the world". It was elaborated in view of the evident need to set out standards for good project management, defining how work should happen throughout the life cycle of a project.

According to Xavier (2012, p. 1), the PMBOK Guide® does not bring a project management methodology, but rather that the "Guide addresses only "what is necessary for project management, without entering into the merits of "how" these processes should be carried out and in what sequence". Given the effectiveness obtained by companies that adopt PMBOK®, it was recognized in 1999 by the American National Standards Institute (ANSI) as a standard for project management.

In order to keep the PMBOK Guide $\AA$ always up to date, every four years checks are elaborated consistent with the current moment of society, regarding new needs and technologies.

While the first. edition of the PMBOK Guide $\circledast$, launched in 1996 by PMI, brought instructions for career improvement in Project Management, in its 7th. edition, updated in 2020, agile, adaptive and hybrid approaches (mixing of traditional and agile) were inserted, applicable in possible contexts and scenarios of the different projects.

In turn, the growing demand of agents from various industries led PMI specialists to develop and publish several specific extensions or guides, to better direct managers from different areas.

RC: 99138

Access Link: https://www.nucleodoconhecimento.com.br/engineering-mechanicalengineering/integration-management 
With regard to the Construction industry, the 1st was elaborated in 2003. version of the Manual Construction Extension to the PMBOK® Guide,or Extension of the PMBOK Guide $\AA^{\circledR}$ for Construction, which addresses the needs of this sector.

Providing guidance specifically for Construction projects, the Construction Extension To The PMBOK® Guide provides Project Management professionals with guidance and guidance on additional areas not found in the Base Guide, as described in Best's articles (2021), and those from CBIC (2020 and 2021), to highlight:

- Recursos: compreende os recursos humanos, os técnicos, e ainda os recursos em equipamentos, materiais e serviços;

- Integridade, Segurança e proteção do projeto e gerenciamento ambiental: traz uma abordagem protetiva direcionada ao ambiente do canteiro de obras;

- Gerenciamento Ambiental: aborda a questão da localização do projeto, tendo em vista existir uma forte influência em projetos de construção, como as questões que envolvem o solo e o clima, aspectos que afetam diretamente o escopo, o cronograma e os recursos destinados ao projeto. $O$ isolamento do projeto relativamente aos centros urbanos impacta a infraestrutura e a logística do mesmo;

- Gerenciamento financeiro do projeto: Aborda os recursos para o financiamento da Construção, incluindo desde a obtenção do financiamento e seu gerenciamento, assim como o faturamento e o monitoramento do fluxo de caixa;

- Reinvindicações (pleitos): trata das contestações e disputas entre as partes interessadas, quanto às mudanças de escopo, cronograma e riscos, entre outros.

Also interesting are the references dedicated to Life Cycle Management and Life Cycle Cost, as well as all aspects related to the environment and social responsibility.

RC: 99138 
The first. edition of the PMBOK® Guide Extension for Construction was published in 2002, while the last update was in 2016. This last edition maintains the same structure as the Base Guide, containing preface, introductory chapters, areas of knowledge, attachments and appendices, in addition to following the organization of the areas of knowledge and the scheme of the groups of processes of initiation, planning, execution, monitoring and control, and closure.

Since it is a material directed to the Construction industry, this Extension of the PMBOK

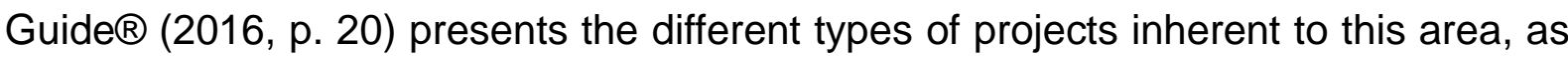
shown in Table 1.

Table 1 - Mapping of process groups and areas of knowledge

\begin{tabular}{|c|c|c|c|c|c|}
\hline \multirow[b]{2}{*}{ Áreas de Conhecimento } & \multicolumn{5}{|c|}{ Grupos de Processos em Gerenciamento de Projetos } \\
\hline & $\begin{array}{c}\text { Grupo de } \\
\text { Processo } \\
\text { de } \\
\text { Iniciação }\end{array}$ & $\begin{array}{c}\text { Grupo de } \\
\text { Processo } \\
\text { de } \\
\text { Planejamento }\end{array}$ & $\begin{array}{c}\text { Grupo de } \\
\text { Processo } \\
\text { de } \\
\text { Execução }\end{array}$ & $\begin{array}{c}\text { Grupo de } \\
\text { Processo de } \\
\text { Monitoramento } \\
\text { ou Controle }\end{array}$ & $\begin{array}{c}\text { Grupo de } \\
\text { Processo de } \\
\text { Fechamento }\end{array}$ \\
\hline $\begin{array}{l}\text { 4. Gerenciamento de Integração em } \\
\text { Projetos }\end{array}$ & 国 & 国 & 봄 & 国 & 亶 \\
\hline 5. Gerenciamento de Escopo em Projetos & & 돌 & & 匽 & \\
\hline $\begin{array}{l}\text { 6. Gerenciamento de Cronograma em } \\
\text { Projetos }\end{array}$ & & 홈 & & 酔 & \\
\hline 7. Gerenciamento de Custo em Projetos & & $\mathbf{E}$ & & 睲 & \\
\hline $\begin{array}{l}\text { 8. Gerenciamento de Qualidade em } \\
\text { Projetos }\end{array}$ & & 醘 & 国 & 国 & \\
\hline $\begin{array}{l}\text { 9. Gerenciamento de Recursos em } \\
\text { Projetos }\end{array}$ & & 䤈 & E & • & - \\
\hline $\begin{array}{l}\text { 10. Gerenciamento de comunicação em } \\
\text { Projetos }\end{array}$ & & $\mathbf{E}$ & 圆 & 㽬 & \\
\hline 11. Gerenciamento de Risco em Projetos & & 畺 & & 回 & \\
\hline $\begin{array}{l}\text { 12. Gerenciamento de Aquisições em } \\
\text { Projetos }\end{array}$ & & $\mathbf{n}$ & 国 & 효 & 回 \\
\hline $\begin{array}{l}\text { 13. Gerenciamento de Partes Interessadas } \\
\text { em Projetos }\end{array}$ & 监 & : & $\mathbf{E}$ & 高 & \\
\hline $\begin{array}{l}\text { 14. Gerenciamento de Saúde, segurança } \\
\text { seguridade e ambiental em Projetos }\end{array}$ & & - & - & - & \\
\hline $\begin{array}{l}\text { 15. Gerenciamento Financeiro em } \\
\text { Projetos }\end{array}$ & & - & & - & \\
\hline
\end{tabular}

Source: Translation of the author, based on PMI (2016, p.20) 


\subsection{GOOD PRACTICES UNDER CONSTRUCTION ACCORDING TO THE EXTENT OF THE PMBOK® GUIDE}

Data from the Brazilian Chamber of Construction Industry (CBIC) show that the Construction sector accounted for $3.4 \%$ of Brazil's Gross Domestic Product (GDP) throughout 2020, providing employment to 2.269 million workers.

This segment led to the creation of 45,249 new job positions, a number that consists of the difference between 152,553 admissions and 107,304 layoffs. Put another way, construction was generated above $" 100,000$ formal jobs by September 2020, according to data presented by the new CAGED, and released by the Special Secretariat of Social Security and Labor of the Ministry of Economy" (CBIC, 2020b).

In the United States of America, home to the Project Manager Institute - PMI, the construction industry participates with $4.3 \%$ of GDP and employs 11.8 million workers (CBIC) (2020b).

At first, it is worth noting that the size of the Construction industry justifies the fact that the PMI has developed a specific guide, containing the good practices focused on this sector. The impact of the Construction industry and its fundamental importance on the economy of different countries justifies the creation - by the PMI - of a guide of good practice specific to this sector, an action that enriched the PMBOK Guide $\AA$, before the publication of the Extension of the PMBOK Guide $\AA$ for Construction, dedicated to detailing concepts and practices of success.

According to the Extension, sections 1 through 3 describe the structure and specific characteristics that are unique to construction projects, their project lifecycles. In turn, sections 4 to 13 correspond to the ten Areas of Knowledge described in the PMBOK Guide $\AA$, presenting additions or modifications, describing specific attributes for the Construction industry, in addition to emphasizing those activities and practices that are of unique importance in this sector (PMI, 2016).

RC: 99138

Access Link: https://www.nucleodoconhecimento.com.br/engineering-mechanicalengineering/integration-management 
In such an important segment, the adoption of strategic construction management makes it possible to achieve positive results (BEST, 2021). However, all this starts long before the first movement at the construction site - since the change must begin in the projects; therefore, the concepts of $\mathrm{PMBOK} \AA$ and the good construction practices dealt with in the Guide Extension address characteristic themes, which will be described from this stage of this article, based on it.

1. Specialized target audience of the Construction industry: there are a significant number of Stakeholders in a Construction project, mainly in works of great complexity and high financial resources (PMI, 2006, p. 4).

The main ones, but not limited to them, are: Construction managers, project managers, Contractors, Subcontractors, estimators, programmers, cost engineers, project control analysts, architects, designers, engineers; Experts in risk management, Specialists in geotechnical and hazardous materials, Regulatory agencies and governments, nongovernmental organizations (NGOs) and private companies; Environmental groups, community groups, prospective homeowners, real estate developers, vendors and suppliers of construction materials and equipment, logistics and transportation specialists, construction consultants and lawyers, insurers, banks and financial institutions. In summary, here are all stakeholders in the construction process, from the acquisition of the land to the design, construction and occupation.

2. The organizational structure of the Construction projects - Project, Program and Portfolio: according to the PMBOK® Guide Extension for Construction, the role and size of an organization often determine whether it will manage its projects within portfolios or programs. The classification and definition of the size of managed projects is up to the organization - between small, medium and large - and thus, how such projects must follow within the corporate structure, that is, whether they will be treated as programs or as projects within the organization (PMI, 2016, p. 5).

RC: 99138

Access Link: https://www.nucleodoconhecimento.com.br/engineering-mechanicalengineering/integration-management 


\section{The role of the PMO project office in the Construction industry: Within a} Construction project there is a focus on maintaining consistency in the management and execution of projects. Some projects may be referred to as best practices in addition to common PMO practices.

According to the PMI Guide Extension (2016, p. 6-7), practices especially important for the Construction industry can be:

1) o registro histórico de projetos para utilização em estimativa de custos e licitação; 2) práticas em processos de Saúde Ocupacional, segurança, proteção e gestão ambiental; 3) procedimentos de garantia de qualidade e inspeção de terceiros para controle de qualidade; 4) práticas em administração de contratos;

5) práticas em administração de subempreiteiros, vendedores e fornecedores;

6) melhores práticas na gestão de reivindicações, gestão de pedidos e reclamações.

4. The role of the Construction Project Manager: there are very specific characteristics in the Construction industry, and it is possible that there are project managers working with stakeholders in a single work/project. Whether this position resides with the contractor (service seller) or with the owner (purchaser of the services), the project manager must have the knowledge, experience and competence to understand and define the interrelationships between the project and the project management components.

According to the Guide Extension, the role of the project manager in Construction requires specialized knowledge, because management issues are the main causes of problems in a project of this industry (PMI, 2016, p. 7).

5. Interested Public Parties: accordingto the Guide Extension, the construction industry often works under the public scrutiny, essentially consuming revenue stemming from taxpayers; thus, public criticism or interference may directly or indirectly affect the project (PMI, 2016, p. 8).

6. Other standards: many projects are subject to compliance with normal and government codes or legislation (PMI, 2016, p. 8).

RC: 99138

Access Link: https://www.nucleodoconhecimento.com.br/engineering-mechanicalengineering/integration-management 


\subsection{CONSTRUCTION ENVIRONMENT AND THE IMPACTS OF EXTERNAL FACTORS}

The guide brings light to an important feature of the projects executed in this industry, which consists of the relevance of the location of the project. Considerations about local geography, existing infrastructure, local population and distance from urban centers, among others, are characteristics that can influence the time, costs and methods of construction/installation of projects. Even the financing of the project can be impacted by the environment and construction site (PMI, 2016).

It is also worth noting here that not only the internal factors directly linked to construction projects are able to influence and interfere in the management of projects in this segment, but also the environmental factors that are, in their predominance, external. The Guide Extension (PMI, 2016, p. 9), explaining that the main factors that "influence the results of the construction project, for example, presents the economic, financial and location aspects of the site".

Another relevant aspect considered in the Guide Extension (PMI, 2016, p. 13) refers to the location of the environment, due to the strong possible impacts on the project. The geographical issue can lead to more expensive costs during the construction period, in the case of a region with different soils, which may require adaptations only discovered when the construction stages are started.

Also with regard to the location of the project to be carried out, are the possible needs of training of local labor, which should be done from the beginning of activities, when it comes to works in regions that do not have the necessary infrastructure to support the volume of labor during construction. Finally, and not least, is the question of logistics for the arrival of materials or equipment, since needs may arise regarding the adaptation or construction of conditions and place of packaging of them.

\subsection{PROJECT DELIVERY METHODS}

RC: 99138

Access Link: https://www.nucleodoconhecimento.com.br/engineering-mechanicalengineering/integration-management 
The Delivery Method of a Construction project depends on the project environment, and its choice is influenced by factors such as: type and size of the construction; federal and state legislation; owner's activity; level of knowledge and experience; expertise and time dedicated to the project. The method will also directly impact the strategy for hiring equipment, tools, materials and services (PMI, 2016, p. 10).

The Extension of the PMBOK® guide Construction Guide (2016) presents some methods used as best practices, the most common being: Project-constructionelaboration; Project - construction; Enginnering, Procurement and Construction (EPC) or Engineering, acquisition and construction; Self-performance; Integrated Project Delivery (IPD) or Integrated Project Delivery and Public-Private Partnership (PPP).

In large projects, especially in the case of major works, the delivery method most used by the Construction industry is Engineering, Acquisition and Construction (EPC). The use of this delivery method occurs - mainly - by seeking to mitigate the contractor's risk, since it is a global contract in which the contractor - which is usually a contractor with robust technical and financial capacity.

In cases such as this, a large contractor usually assumes the obligation to carry out the engineering project, perform all the activities inherent to its scope, provide - by its own sources or third parties - all the materials and equipment necessary for the enterprise, and also install, assemble, test and commission such equipment, so that the work is completed within a specified period, and delivered to the operation.

There are variations in the scope of the contractor in performing or not some specific steps, such as testing and commissioning.

In complex projects it is possible to verify the existence of structures that have several contracts with complementary scopes, that is, when there are separate contracts for technology, basic and detail engineering, civil construction, assembly, management, among others. Each of these contracts includes the EPC services corresponding to your area.

RC: 99138

Access Link: https://www.nucleodoconhecimento.com.br/engineering-mechanicalengineering/integration-management 
In cases where one of the Interested Parties is made up of public servants through governments or public bodies, the delivery method normally used is the Public-Private Partnership (PPP). In the universe of PPPs, typical project delivery methods include concessions, Build, Operate and Transfer (BOT) or build, operate and transfer, and Design Build Operate Mantain (DBOM) or design, build, operate and maintain.

\subsection{LIFE CYCLES OF CONSTRUCTION PROJECTS}

All the information for the beginning of a project is fragile. Thus, at the beginning of the execution phase, problems arise that must be corrected for the success of the work. In this perspective, and according to the guidelines of the good practices of the Extension of the PMBOK® Guide Construction Guide (2016), most of these projects have a life cycle consisting of the design, design, construction, commissioning and closure, although this industry usually takes the reformulation of some of these phases.

In practice, the Construction industry subdivides the entire process into more phases, each of which corresponds to the perspective of the interested party, from the point of view of the project owner. As an example, one can mention phases such as Development, for which the initial project information prospected makes sense, differently from a contractor's perspective.

In this sense, Molwus (2014, p.58) explains that:

As principais decisões (propostas e projeto executivo) relativos ao projeto são efetuados na fase de preparação do investimento, que é seguido pela fase de execução do projeto, durante o qual os trabalhos são realizados no local, de modo a realizar os objetivos do projeto, com base nas decisões e escolhas feitas durante o projeto executivo. Após a fase de execução é a fase de operação, onde se espera que benefícios do projeto sejam extraídos (tradução livre).

One of the characteristics of the Construction industry is that many aspects of the projects are established at the beginning of the Project Life Cycle, when there is greater uncertainty; at this stage, some contractual scopes are signed and contractual changes are an additional challenge.

RC: 99138

Access Link: https://www.nucleodoconhecimento.com.br/engineering-mechanicalengineering/integration-management 
Hiring contractors at the beginning of the Project Lifecycle can be time-effective, but the degree of Project Information Development may affect cost and consuntibility and contracting alternatives. It is stated in the Extension of the PMBOK® Guide for Construction, that "contracts, which are drafted and agreed during the period of greatest uncertainty, should include provisions for a fair and appropriate distribution of risks associated with emerging issues" (PMI, 2016, p. 17).

This is a good practice, which aims to divide the risk between contractor and contractor, but still does not eliminate future costs, given the initial indefinitions of the project. Since contracted companies can issue budgets and price rates based on a certain amount of material, workload of equipment resources in smaller quantity than necessary, a situation is evidenced that will require a contractual rebalancing.

In projects that require high investments it is common to be used for their processes, predictive life cycles, aiming to reduce risks and maximize the probability of success; are of the type of time-limited processes, known as Front-End Loading (FEL) or PreProject Planning, which refers to the realization of a solid planning and project in early stages (or Front-End of the project).

The FEL process includes decision-making moments (usually three: FEL1, FEL2 and FEL3) in well-defined milestones, when the decision is made that the next step will be made.

The PMBOK® Guide Extension For Construction provides an overview of the information that is typically developed before each phase port; however, the organization executes its milestones according to its resources and objectives (PMI, 2016, p. 17).

RC: 99138

Access Link: https://www.nucleodoconhecimento.com.br/engineering-mechanicalengineering/integration-management 
Table 2 - FEL stage portal payables

\begin{tabular}{|c|c|c|}
\hline FEL 1 & FEL 2 & FEL 3 \\
\hline $\begin{array}{l}\text { - Objetivos de performace } \\
\text { - Avaliação das alternativas } \\
\text { tecnológicas } \\
\text { - Estudos de viabilidade } \\
\text { - Cronograma de marcos } \\
\text {-Investimento estimado } \\
\text { (+50\%), Estimativa de } \\
\text { despesas operacionais } \\
\text { (+100\%) }\end{array}$ & $\begin{array}{l}\text {-Engenharia conceitual e } \\
\text { Básica } \\
\text { - Avaliação técnica } \\
\text { - Cronograma Conceitual } \\
\text { - Orçamento estimado } \\
\text { (+30\%) } \\
\text { - Identificação de itens } \\
\text { financiáveis }\end{array}$ & $\begin{array}{l}\text {-Projeto de engenharia } \\
\text { (FEED) (desenhos técnicos, } \\
\text { fluxogramas) } \\
\text { - Plano preliminar de compras } \\
\text { e aquisições. } \\
\text { - Escopo do trabalho } \\
\text { - Cronograma de recursos } \\
\text {-Orçamento definitivo } \\
\text { (+10\%) }\end{array}$ \\
\hline
\end{tabular}

Source: Translation of the author, based on PMI (2016, p.17).

In general, by using the concepts of Front-End Loading (FEL) in Construction projects, the risk of the project is reduced, and the owners have a greater amount of strategic information, leading to a project more related to business decisions. The FEL application allows team members to think about all subsystems and impact factors.

Adaptive Life Cycles, also known as agile or change-oriented methods, are intended to facilitate this change by requiring a high degree of ongoing stakeholder engagement. Adaptive methods are generally preferred when it comes to a rapidly changing environment, when requirements and scope are difficult to define in advance. In turn, RC: 99138

Access Link: https://www.nucleodoconhecimento.com.br/engineering-mechanicalengineering/integration-management 
when it is possible to define small incremental improvements, these will provide value to stakeholders.

Construction projects are, by nature, a deterministic activity, more complex and resistant in adopting Adaptive Life Cycles. In large projects, the acquisition of critical equipment is usually carried out months in advance of its effective applications on the construction site. When differences arise between the versions of the data emitted in the basic project and the data after the acquisition of materials and equipment, it becomes a situation that can generate impact in previous versions, reducing the space for adaptations or changes.

Depending on the objective of the project, the Adaptive Lifecycle can be replaced by a competing model, in which the phases can overlap, that is, the Interactive Lifecycle model must be adopted.

As an example, it can be mentioned that in the adaptations of construction processes defined during the basic project, there are changes in the detailing project and the replanning of this activity, which can be done interactively, through a series of repeated cycles, as the project progresses.

In this regard, Molwus (2014, p. 58) argues that "at different stages of the project there will be stakeholders coming and going, as well as interrelating with elements of the project or other stakeholders".

\subsection{STAKEHOLDER INTEGRATION MANAGEMENT}

By definition, stakeholders consist of the group of people involved in a Construction project. According to the Extension of the PMBOK® Guide for Construction (2016, p. 135), there are direct participants involved with a given project, they are: "project participants, project owners, architects or design engineers, contractors, subcontractors and material suppliers".

RC: 99138

Access Link: https://www.nucleodoconhecimento.com.br/engineering-mechanicalengineering/integration-management 
In turn, the indirect participants of a Construction project are such a composite group (PMI, 2016, p. 135):

\begin{abstract}
agências ou autoridades reguladoras (isto é, em relação à segurança, saúde ocupacional e meio ambiente). questões); Associações profissionais; Público em geral, incluindo residentes locais, grupos; Proprietários de terras e pessoas afetadas por projetos; Sindicatos de trabalhadores; Departamentos do governo local; Mídia; lobistas ou grupos de peticionários; outros empreendimentos de construção que possam afetar o projeto; Representantes e associações nacionais da indústria ou de empresas; e Polícia e outros serviços de emergência.
\end{abstract}

Another important aspect to highlight, with regard to stakeholders, is the fact that, according to the geographical location and specificities of certain construction projects, there may be other stakeholders entering such a project. In other cases, both direct and indirect participants are not limited only to those mentioned above.

Among all these steps, Da Rosa and Esteves (2016, p. 13) highlight the Management of The Integration of Stakeholders, standardized in Brazil according to NBR ISO 21500, 2012, according to the Brazilian Association of Technical Standards (ABNT). The authors explain that in the process of completing a project, there must be harmony between all the parts that integrate it. It is equivalent to saying that customers, managers, and other participants are in agreement and satisfied, as shown in Figure 3.

RC: 99138

Access Link: https://www.nucleodoconhecimento.com.br/engineering-mechanicalengineering/integration-management 
Figure

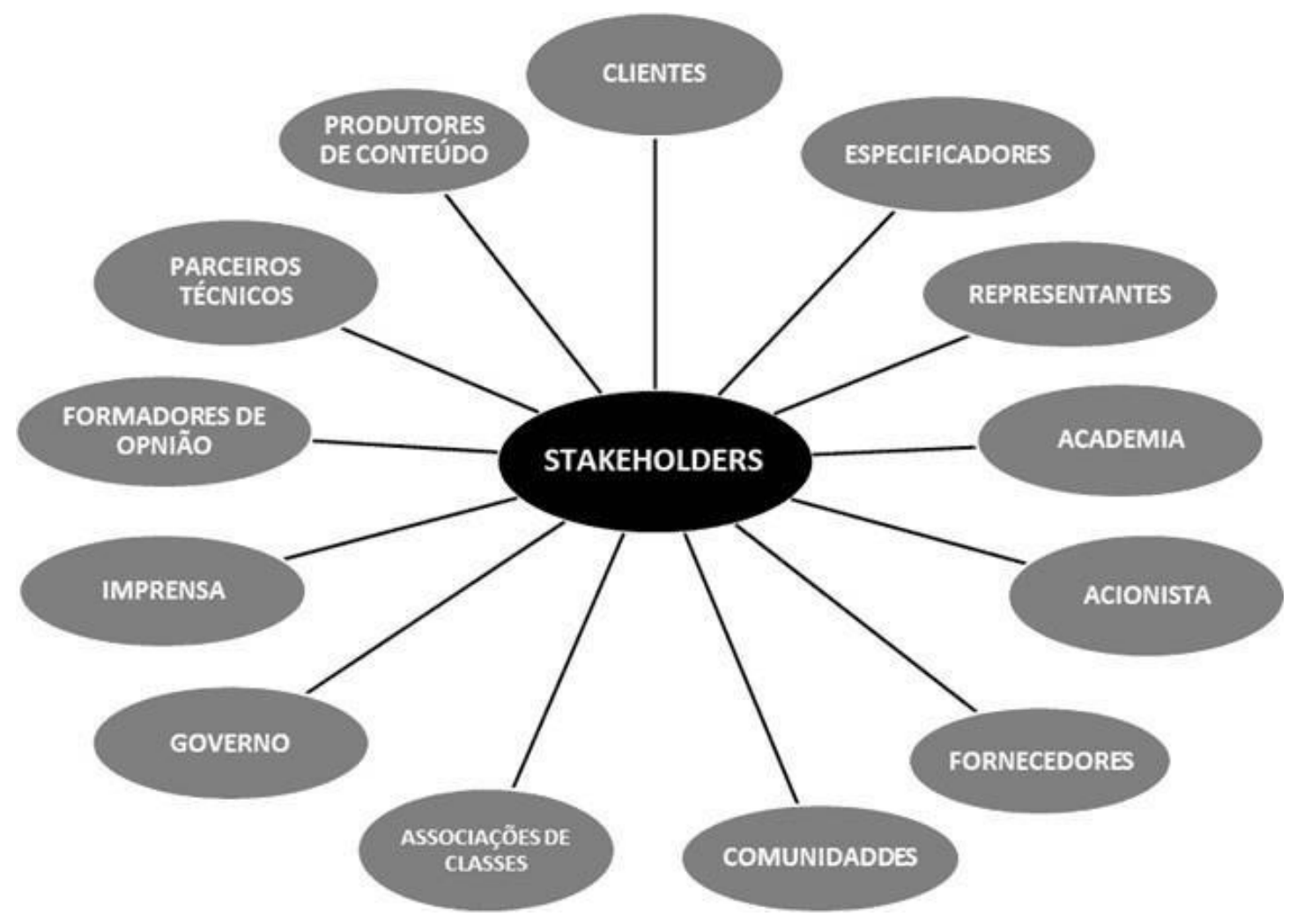

Source: Author's elaboration, based on Portal Fixe (2012)

Siqueira; Menezes e Oliveira (2018, p. 4-5) argue that the PMBOK Guide itself® (2013) defines that "the Management of stakeholders of the project includes the processes required to identify all people, groups or organizations that may impact or be impacted by the project". However, PMBOK® also points out that "everyone involved in a project should be inserted, not just those who hold the financial or command power over the decisions and strategies to be followed."

Despite the reservation of PMBOK®, Siqueira et al. (2018, p. 5) refer Robbins (2005, p. 302) to argue that "a person can only have power over you if they control something you want." In this sense, Siqueira et al. (2018, p. 5) highlight the importance of relationships, expectations, inclinations and levels of influence of the power exercised by stakeholders, in relation to the others involved, in view of decisions and the [...] RC: 99138 
"strategic direction of the project according to the group involved and the degree of power of each stakeholder".

These authors also present the definition of stakeholders, defended by Xavier (2006, apud SIQUERA et al., 2018, p. 5):

Gerente de projetos: a pessoa responsável pelo gerenciamento do projeto;

Cliente: a pessoa ou organização que irá utilizar o produto ou serviço do projeto;

Membros da equipe: as pessoas que compõem a equipe do projeto;

Organização executora: a empresa em que o projeto está sendo executado;

Patrocinador (sponsor): a pessoa ou o grupo, dentro ou fora da organização executora, que provê recursos financeiros e/ou apoio institucional para a execução do projeto.

For Montes (2020), the PMBOK® guide aims to create strategies that involve all stakeholders - breaking their resistance in issues/moments when they disagree with each other.

By agreeing with the definitions given by Xavier (2006), Montes (2020) still reinforces them: there are clients related to Project Management, responsible for planning, involvement of the parties and for all actions and stages of the project, in the direction of its objectives.

\subsection{UTILITY-SCALE SOLAR ENERGY UNDER CONSTRUCTION}

\subsubsection{ENERGY MATRICES}

According to Inatomi and Udaeta (2005), it was from the Industrial Revolution that natural resources began to be explored very quickly and intensely, without care or RC: 99138

Access Link: https://www.nucleodoconhecimento.com.br/engineering-mechanicalengineering/integration-management 
concerns about the technologies developed and possible social damage and the environment, causing the enormous environmental impacts already known in the present. These authors refer to the impacts generated on the environment - without considering the finitude of natural resources - by humanity to dynamically cover the energy sector, affected by socioeconomic reasons, implying responses from the social, economic, political and environmental dimensions (INATOMI and UDAETA, 2005, p. 190).

They also highlight that, from a global perspective, it is estimated that the consumption of " $80 \%$ of the energy consumed comes from the burning of fossil fuels (coal, oil and natural gas)" (COSTA, 2005, apud INATOMI and UDAETA, 2005, p. 191).

\subsubsection{SOLAR ENERGY}

Renewable energies "are any means of energy from biological, geophysical or solar sources, which are recomposed at a speed equal to or greater than their consumption," as described in the report of the UN Integrated Panel on Climate Change (SERVOS, 2016, p. 12). According to the National Electric Energy Agency (ANEEL) (2002), "solar radiation can be used as a source for the generation of thermal, electrical and mechanical power".

According to Daros (2013, p. 15), solar radiation is converted into electrical energy from "thermoelectric and photovoltaic" contact effects. While the passive use of solar energy provides heat and lighting, thermal use takes place through solar collectors or concentrators, causing the heating of fluids in domestic buildings, for example. With regard to "electricity generation, it is due to the effects of radiation (heat and light) on certain materials" [...] " that is, "the photovoltaic effect, which results from the excitation of electrons of some materials in the presence of sunlight" (ANEEL, 2005, apud DAROS, 2013, p. 15).

Solar energy can produce electricity when in contact with photovoltaic plates, since they are composed of several silicon plates, whose electrons "are energized to contact RC: 99138 
with sunlight", which allows the generation of electricity for residential or commercial constructions. Unlike other forms of electricity generation, the "photovoltaic system is obtained directly and produces with this electric current, which is processed by controlling devices and converters, which are stored in batteries or used directly in systems connected to the electricity grid" (VILLALVA, 2015, apud PINA and CORRÊA, 2018, p.17).

\subsubsection{INSTALLATION OF A SOLAR PARK}

In view of the global population growth, and with the advance of different technologies and sectors, in the search for alternative sources of renewable energy and its adoption, is photovoltaic energy. However, of high cost for a large part of the consumer population, "solar condominiums emerged, which at the same time would produce energy for several consumers, cheaping the equipment, because it is a large-scale purchase" (PINA and CORRÊA, 2018, p. 14).

According to Guarnieri (2017, p.40), the main stages of development of a solar project are:

Primeiro contato, ideia inicial e descrição geral do projeto;

Avaliação do site - aspectos técnicos e legais: verificação prévia do ponto de conexão; adequação do terreno adequado à instalação em região com bom índice de irradiação solar; estudo da geração solar preliminar;

Desenvolvimento do projeto básico preliminar: consulta do acesso à rede; análise de investimento; contrato de compra/aluguel do terreno; estudo ambiental e obtenção do Licenciamento Prévio; medição de dados ambientais e certificação da produção de energia;

Cadastramento da usina para habilitação (em caso de participações em leilões federais);

Projeto básico: orçamento dos principais componentes; Construção; custos administrativos e O\&M; avaliação econômica para acerto de preço da energia negociada;

Leilão de energia: PPA - Contrato de compra de energia; Contratos da SPE;

RC: 99138

Access Link: https://www.nucleodoconhecimento.com.br/engineering-mechanicalengineering/integration-management 
Fonte garantida de recurso para implantação (financiamentos ou investimentos privados);

Viabilização do ponto de conexão;

Negociação com principais fornecedores: solicitação de propostas; roteiro para avaliação das propostas técnicas e econômicas;

Levantamento de custo e alternativas de implantação;

Projeto executivo: consolidação das especificações dos equipamentos e materiais; elaboração de desenhos de projetos e listas de compras; cronograma da construção;

Aquisição de materiais;

Construção: preparação do site e mobilização; atividades de caráter civil e montagem eletromecânica; testes de operação: testes elétricos, comissionamento;

Inauguração.

The construction activities of a solar park are very intertwined with the specific needs of the equipment to be installed. Among the stages of the work of a UFV, Guarnieri (2017, p.48) details the initial stage of the construction process itself:

Etapa de obra civil: inicia com o processo de supressão vegetal, confirmação da topografia e terraplanagem quando necessário, construção de acessos internos e posterior confecção das valas de drenagem e de encaminhamento de cabos;

Etapa de montagem mecânica: é composta pela instalação das fundações, posterior montagem das traves e mesas de suporte e finalmente a fixação dos módulos fotovoltaicos;

Montagem elétrica: quando as conexões dos módulos são efetivadas e ocorre o encaminhamento dos cabos de baixa tensão até as caixas de junção e inversores. Nos eletrocentros ocorre a elevação da tensão e então os circuitos de média tensão são encaminhados para a subestação de concessão da usina. Todos os elementos são também devidamente protegidos através de instalação de um adequado sistema de aterramento e proteção.

Comissionamento: antes da conexão e início da operação da usina, os elementos componentes da usina são inspecionados visualmente e através de testes mecânicos e elétricos, certificando o projeto e os parâmetros previstos de operação.

RC: 99138

Access Link: https://www.nucleodoconhecimento.com.br/engineering-mechanicalengineering/integration-management 
As described by Pinho and Galdino (2014, p. 144), the basic components of a photovoltaic system are: solar modules, batteries, inverters, metal structures, electrical cables and substation. Each of the related items has its own characteristics and particular needs for installation and operation, referring to the next step, which is the integration of all the different functionalities, manufacturing steps, transportation and installation on the site of the solar park construction project.

Among the basic items are the metal structures, which are the equipment to support the solar modules, and can be fixed structures or that have the functionality of following the solar position, also called trackers or solar trackers.

In order to define an optimized configuration for the project, regarding the assembly of metal structures, studies and analyses of various information should be carried out, such as a geological study of the soil, from a pull out tests, to survey soil resistance information, including:

Soil identification and classification tests: the most relevant assays consist of mineralogical analysis, particle size analysis, WNAT determination (Natural Soil Moisture), volume weights and Atterberg limits;

Standard Penetration Test (SPT): aims to determine, in depth, soil resistance to dynamic penetration;

DPSH assay: it is subdivided into DPSH-A and DPSH-B, according to the hammer fall height being $0.5 \mathrm{~m}$ or $0.75 \mathrm{~m}$, respectively, with hammer mass of $63.5 \mathrm{~kg}$. The DPSH reaches depths greater than $25 \mathrm{~m}$, and the number of blows is registered to register the conical tip of $10 \mathrm{~cm}(\mathrm{~N} 10)$ or $20 \mathrm{~cm}$ (N20).

The association between the tests is frequent in the activities of geotechnical characterization of areas with some dimension, allowing to combine a wider mesh of SPT tests with a tighter of DPSH tests, faster and more economical to be performed, resulting in a more complete characterization of the terrain.

RC: 99138

Access Link: https://www.nucleodoconhecimento.com.br/engineering-mechanicalengineering/integration-management 
It is not the focus of this experience report to detail each stage of the tests performed, but to have them as a reference, in order to contextualize the criticality in projects to build information from project documents. The results presented in the various reports serve as parameters to identify acceptable limits for the efforts to be supported by the soil, dimensioning of structures and definition of constructive alternatives to be applied in the field.

With the information from the tests, one can plan the other stages of construction of the enterprise. Geological tests will strongly interfere in the construction and mechanical assembly stage, reported below.

\subsection{EXPERIENCE REPORT}

There is consensus in the literature that civil engineering projects - - tend to delay, and thus present new financial projections for their implementation, and may have their final cost increased.

In this regard, Xavier (2012, p. 3) states that scientific articles based on field research show that the problem lies in not meeting deadlines, although deadline management is the main focus of every project. This author also explains that, in practice, delays are consequences of different factors, such as problems with suppliers, or risks not properly evaluated, among others.

In this sense, what we want to demonstrate is the importance of consistently considering and integrating the nine (9) areas of knowledge proposed by the PMBOK® Guide (PMI, 2008): "scope, time, cost, quality, human resources, communications, risk, acquisitions and integration".

It happens that in addition to the realization and implementation of a project in the Construction Industry, in addition to the responsibilities inherent to Project Management, changes occur over time.

RC: 99138

Access Link: https://www.nucleodoconhecimento.com.br/engineering-mechanicalengineering/integration-management 
From this perspective, Sousa et al. (2020, p. 13) teach that the more Project Management has consolidated, the importance given to the Project Manager was significantly highlighted. The Project Manager is responsible for absorbing the following changes, which occur over time:

- A single person has full responsibility for the project;

- Employees are dedicated to projects and not to functions;

- Unique coordination between functional interfaces;

- The integrated planning and control used appropriately.

This Report is based on the experience carried out during the construction and assembly of a Solar Power Plant in utilitarian scale in the province of San Juan, Argentina. The project began in 2018, and the final stages of civil earthmoving activity to start the assembly of the structures occurred in January 2019.

The Mechanical Engineering group was composed as this: a mechanical engineering manager - bachelor of mechanical engineering and with strong experience in project management and in the implementation of solar projects; three mechanical engineers with experience in other industries.

The project had a corporate engineering area of the project owner and responsible for executive projects, as well as the support of the engineering department of the tracker manufacturer, located in the state of California, USA.

The method of delivery of the project used was by contract of Engineering, Procurement and Construction (EPC), which, according to the Extension of the PMBOK® Guide Construction (2016, p.10-11), is the outstanding delivery method in the Construction industry.

\subsubsection{THE MANAGEMENT APPROACH}

RC: 99138

Access Link: https://www.nucleodoconhecimento.com.br/engineering-mechanicalengineering/integration-management 
Since it is at the time of the execution of the project in the field that the inconsistent data in the construction drawings, developed in the previous stage, when arriving at the enterprise, it is usual that the professional involved in the construction project management consult the documents previously prepared, to become aware of the information collected during the studies and analyses carried out and used for the development of other engineering documents. The geological studies, the documents of equipment suppliers are consulted, in the case in reference attention was given to the technical needs to be met for the assembly of the structures (trackers).

In this context, the interactions involving the disciplines of civil engineering and mechanical engineering regarding the activities of leveling the ground were identified to comply with tolerances of level and slope.

Some suppliers have different equipment configurations to allow assembly in different terrain conditions.

The difference in dimensions at different points of the terrain impacts on the headtime versus set-up necessary to ensure the resistance of the structure to wind efforts.

In this stage of information analysis, in the respective project, problems were identified in surveyes of topography used for the leveling of the terrain. The location of the project, close to the Andes region, presented specific aspects that directly interfere with the technical specifications.

In January 2019, the project schedule was under enormous pressure, as several critical paths pointed to an extension in time for the completion of the assembly stage of mechanical structures, due to the inconsistency of geological data, which would negatively impact the entire schedule, causing additional costs. The need for rapid responses was evidenced to mitigate the divergence in the base schedule.

The reported project life cycle basically followed the good practices of the Construction industry, consisting of design, basic design, executive design, construction, RC: 99138 
commissioning, network integration, and operation and maintenance. Following the pattern of construction projects, many aspects were established at the beginning of the Project Life Cycle when uncertainty is greatest; thus, it was necessary to adapt the replanning of activities and the inclusion of additional step withon-site verification ofall executive drawings, and conducting geological and technical tests.

In a deterministic process it would be up to the field team to report the inconsistencies, and wait for new documents with the adjustments in the process and the impacts in all phases, including the dates. However, supported by the technical experience of professionals in the field and, recounting the ability to manage projects of the most experienced, we chose to follow the path of studies and analysis of various information described previously in the site of the work, that is, "on-site".

The inclusion of verification activities at the site of the work, the documents involved in the elaboration of the drawings to be used during the construction, as well as the performance of tests, was the right decision to optimize the process, instead of retreating the project to the previous engineering stage, with the objective of replanning the construction dates.

At that moment, the decision was made to apply an Adaptive Life cycle model to the project, where steps would overlap and adjust as the work progressed.

According to Oliveira (1995), we can understand as constructibility the ability or ease of this in being built. This concept expands in order to align technical experience with the premises of the project, through the full knowledge of the constructive technology to be adopted in the enterprise.

According to the PMBOK® Guide Extension Construction Office (2016, p. 06):

Quando acoplada à velocidade com que a informação é distribuída e as decisões são tomadas, um ambiente de projeto de alta complexidade e demanda é criado. Para apoiar este ambiente, espera-se que o gerente do projeto de construção seja adaptável e, em alguns casos, possua uma ampla

RC: 99138

Access Link: https://www.nucleodoconhecimento.com.br/engineering-mechanicalengineering/integration-management 
base de conhecimento em avanços na construção, tais como tecnologia e contratação alternativa de métodos de entrega.

A stakeholder monitoring and control plan was also established, specific to this set of activities. A system was implemented to manage the flow of communication and approval of changes with the areas of engineering of corporate projects, with the suppliers of the structures and with the contractors.

With an efficient workflow of distribution of test results, adjustments were made of project designs and contractor guidelines, supported by short daily meetings, which involved specific groups of stakeholders to understand and solve points of inconsistencies and implementation of solutions. A strong partnership has also been established with the supplier of mechanical structures (trackers).

All these initiatives resulted in an effective dynamics for the management of the work, as well as for the necessary adaptations in the constructibility and assembly of the structures.

In this regard, Tafazzoli and Shrestha (2017, p. 619) present in their study, solutions to avoid the main causes of delays in construction projects, among them, recommend that collaboration between the parties be guaranteed throughout the project, through constant meetings. This allows for integrated decision-making and planning on how to achieve results, considering the integrations between tasks.

\subsubsection{THE TECHNICAL SOLUTION}

The development in question was located near the Andes, requiring a differentiated approach from that used in places that are closer to sea level. The topography curves

RC: 99138

Access Link: https://www.nucleodoconhecimento.com.br/engineering-mechanicalengineering/integration-management 
used as a reference base suffer strong impacts and distortions, due to the altitude of their location.

The ideal procedure to be adopted should use topography curves specific to these sites or, depending on the case, the calculation of a correction factor for the locally collected data during the field topography stage should be elaborated.

This problem interferes in the stages of leveling the ground, with the identification of cut-off and landfill points, as well as in the planning of distribution of spikes of the metal piles, determining their ground headheight (and the respective depth of entry), in addition to the distance between them.

Since trackers have different installation tolerances, which are minimal, which is a detail that requires special attention. To better exemplify, they can be mentioned:

- Slope of piles;

- Twist ing of the pile on its own shaft;

- Free height and minimum depth of crimping to be respected;

- Distance between piles;

- Respect for the different types of piles used, due to the difference between trackers within the same area (external or internal, for example);

- Mounting tolerances of other components, torque/torsion tubes, brackets, inclination and alignment between them etc.

If there is any inconsistency in the initial steps, the tolerances allowed in the following phases may not be sufficient to absorb consecutive assembly errors.

This project had as its premises that the trackers supported the action of winds of up to $115 \mathrm{~km} / \mathrm{h}$, due to the existence of the Zonda wind, very common in the implantation region, and operating temperatures of up to 10 degrees centigrade negative.

RC: 99138

Access Link: https://www.nucleodoconhecimento.com.br/engineering-mechanicalengineering/integration-management 
Such conditions are very difficult for the operation of a solar park, since, when completing the assembly of solar panels on a tracker, the structure must withstand the load of compression and side stresses produced by the wind. The temperature variations are very fast as well and impact on the operation of the couplings and supports, which must adequately absorb the stresses generated by thermal expansion of the various components.

During the field analyses, including geological data and terrain needs for the assembly of trackers, the need for additional surveys of topography of the terrain was identified, in order to identify existing differences, as well as to identify problems in the positioning of the points where the piles would be installed, in order to comply with the distance between them, as well as the free heights of the ground.

It was found as an initial problem the existence of a difference of $+20 \mathrm{~cm}$ between the planned quotas, and those effectively executed in the field. This led to the need to search for technical alternatives that would provide a better use of the piles that were not met with the heights specified in the project.

This survey provided adjustments in the process of leveling the terrain, adjustments in the stake plan, also known as ramming plan, and early corrections of areas with heights above the allowed for the project. As the piles characterized a more closed mesh, $7 \mathrm{~m}$ $x 7 \mathrm{~m}$, while the mesh used for leveling the ground considered one of $20 \mathrm{~m} \times 20 \mathrm{~m}$.

The next stage of the analyses led to the development of crimping criteria, taking into account the type of terrain and the crimping tests carried out at the beginning of the project. Thus, a 6-minute time-out criterion was established for the stake process, and initial production plan.

Another criterion defined was the minimum set-up/crimping limit of the piles on the ground, and consequent headroom, which allowed the alignment and assembly of the other components of the tracker. Some manufacturers allow cutting stakes to be made

RC: 99138

Access Link: https://www.nucleodoconhecimento.com.br/engineering-mechanicalengineering/integration-management 
in order to regularize their height and utilization for assembly of other components; however, there are limits to this use.

Consideration should be given to existing holes for mounting the supports and their distances to the edges of the piles. These distances are calculated to allow a mechanical resistance to the fasteners and the structure itself. It cannot be reduced or increased by too much of these distances in order not to impact the final resistance of the structure.

The data analyses allowed the implementation of three different cutting alternatives in the project, directly in the soil, with pre-hole and concrete use. These alternatives, aligned with the selection criterion by result of pull out tests, led to a greater use of the spikes performed.

In view of the uncertainties during the crimping process, the presence of small rocks in the various layers of the terrain caused a considerable number of piles that did not meet the project requirements, either by height or displacement at the end of the crimping process, causing unwanted displacements and inclinations.

The performance of tests with cutting stakes directly in the ground, with survey of production time, numbers of piles that did not meet the parameters of the project, and search for alternatives that reduced the costs in carrying out this activity, provided the project with its completion within the established deadlines, with records of correction points by the tracker supplier, of few points to be corrected or clarified, to maintain the warranty of the equipment for a period of more than 25 years.

The results obtained with the described approach also allowed the replanning in the subsequent stage of assembly of solar panels, applying the process of compressed activity (crashing), through a concentrated assembly effort in a specific and very short period.

RC: 99138

Access Link: https://www.nucleodoconhecimento.com.br/engineering-mechanicalengineering/integration-management 
The execution was the responsibility of the contractor of the region, due to his expertise for hiring local labor and supply of equipment for the execution of the activities; however, under direct management of the project owner.

This concentration of effort was successful, allowing the installation of more than 54,000 panels, in a period of 12 hours, with a world record in the evaluated period.

\section{FINAL CONSIDERATIONS}

According to all the theories described throughout this article, as well as the actions adopted for the implementation of the project in question, it is observed that the results achieved were important, considering that the stage that previously pointed to a critical path of activities that reinforced the risks in the schedule and costs in the project were mitigated.

For this step, and using as reference the estimated values of standard base projects, we can report that the costs totaled approximately USD $22,780,000.00$, and $20 \%$ of this value is related to direct costs with services of execution of the installation and assembly of trakers and modules.

With the approach developed and the strategies implemented, the economic impact was positive. Considering the standard references mentioned above, the economic gain was in the order of $4 \%$ of the total costs, resulting directly from the recovery of the assembly time of the structures in 04 weeks, as well as a reaction in the other subsequent stages in 06 weeks.

With the action of the assembly challenge of modules, it was possible to produce a quantity of structures and modules installed and ready to advance the stages of electrical interconnection of the modules (serial), release of cables of low voltage networks (BT), interconnection of inverters in the String version, among other constructive steps.

RC: 99138

Access Link: https://www.nucleodoconhecimento.com.br/engineering-mechanicalengineering/integration-management 
It can be affirmed that with the application of differentiated strategies, the project has achieved gains, which go beyond a specific discipline or activity. This differentiated application impacted the performance of other areas, such as Civil and Electric project, as well as in all subsequent stages of the chain.

The above result was possible, in view of the technical approach used, making changes in the initial project and applying methods that gave productivity to the process. As an example, one can mention the adoption of construction processes, through which speed was printed in the crimping of piles to support the structures that support the solar modules.

With the challenge of mechanical assembly of expired structures, it was possible to adopt an approach directed to the management of concentrated efforts of the subsequent stage of installation of solar modules, applying the compression process, which required an assertive management of resources being machines, equipment and people in quantity greater than planned at this phase of the project.

When analyzing the adjustments in the construction processes, and in the search for the reduction of the time of displacement of people, materials, tools and equipment in the construction areas, there was also a greater gain of time in the execution of the work as a whole, allowing a greater advance in the stages of the work.

It is also observed that improving communication and coordination between stakeholders was essential to mitigate the risks of the schedule.

It is concluded that the application of good practices in construction project management, combined with the experience in the field of a strong technical knowledge body, combined with project management expertise, were essential to successfully apply an Adaptive Life Cycle model, where activities and phases were overlapthed in a planned and efficient manner, once the adaptation and replanning of the processes defined during the phase of the basic and detailing design for the assembly of the tracks and installation of the modules, were changed during the RC: 99138 
execution phase interactively, as the project progressed. This in a construction project, whose deterministic nature and large number of stakeholders make the challenge more complex.

\section{REFERENCES}

BEST, Raynor de. PIB e empregos da indústria de construção nos EUA. Publicado em 27 abr 2021. Disponível em: [https://www.statista.com/statistics/192049/valueadded-by-us-construction-as-a-percentage-of-gdp-since-]; acesso em 08/03/2021.

CBIC - CÂMARA BRASILEIRA DA INDÚSTRIA DA CONSTRUÇÃO. Resumo dos principais indicadores do setor da Construção Civil. Sala de imprensa. Artigo publicado em 05 mai 2021. Disponível em: [http://www.cbicdados.com.br/menu/salade-imprensa/sala-de-imprensa]; acesso em 08/03/2021.

. Participação (\%) do PIB da Construção Civil no PIB Total Brasil - 2000

a 2020. Publicado em 2020a. Disponível em:

[http://www.cbicdados.com.br/media/anexos/1.3.1_Sala_de_Imprensa_22.pdf]; acesso em 08/03/2021.

. Construção Civil gerou mais de 100 mil empregos formais até setembro. Matéria publicada em 29 out 2020b. Disponível em: [https://cbic.org.br/construcaocivil-gerou-mais-de-100-mil-empregos-formais-ate-

setembro/\#: :text=Construção\%20Civil\%20gerou\%20mais\%20de\%20100\%20mil\%2 0empregos\%20formais\%20até\%20setembro,-

Em\%20setembro\%2C\%20a\&text=Desse\%20total\%2C\%205\%2C93\%25,\%2C43\%25 $\% 20(45.249)$; acesso em 08/03/2021.

DAROS, Higor Brusch. Integração de fontes de Energia Renováveis. Monografia [Graduação] em Engenharia Elétrica, apresentada à Universidade Federal do Rio Grande do Sul. PA, 2013. Disponível em:

RC: 99138

Access Link: https://www.nucleodoconhecimento.com.br/engineering-mechanicalengineering/integration-management 
[https://lume.ufrgs.br/bitstream/handle/10183/96208/000915410.pdf?sequence $=1$ \&is Allowed=y]; acesso em 08/03/2021.

FARIAS, Raileide Amaral de. 0 gerenciamento da integração como fator de sucesso no Gerenciamento de Projetos Dissertação MBA [Pós-graduação lato sensu] em Gerenciamento de Projetos, apresentada à Fundação Getúlio Vargas (FGV). Salvador (BA). Março de 2018. Disponível em: [https://www15.fgv.br/network/tcchandler.axd?tccid=7839]; acesso em 08/03/2021.

GOMES, Letícia Fernandes Bella; FREITAS, Karine Fátima de; BELLA, Ricardo Luiz Fernandes; DEL-VECCHIO, Renata Raposo; LIMA, Gilson Brito Alves. Centralidade de grafos aplicada à projetos de Energia Renovável. Mix Sustentável. Florianópolis, vol.6, n.4, p.105-114, ago. 2020. Disponível em: [https://redib.org/Record/oai_articulo2788443-centralidade-de-grafos-aplicada-àprojetos-de-energia-renovável]; acesso em 08/03/2021.

GUARNIERI, Mauricio Vivan. Usinas solares fotovoltaicas com seguimento em um eixo no Brasil: aspectos da construção, custos e expectativa de desempenho. Dissertação [Mestrado] em Engenharia Civil, Área de concentração Construção Civil, da Universidade Federal de Santa Catarina. Florianópolis, 2017. Disponível em: [http://fotovoltaica.ufsc.br/Dissertacoes/Dissertacao_Mauricio_Vivan_Guarnieri.pdf]; acesso em 08/03/2021.

INATOMI, Thais Aya Hassan Inatomi; UDAETA, Miguel Edgar. Análise dos Impactos Ambientais na produção de energia dentro do Planejamento Integrado de Recursos. 2005.

Disponível em: [https://www.academia.edu/36538516/ANÁLISE_DOS_IMPACTOS_AMBIENTAI S_NA_PRODUÇÃO_DE_ENERGIA_DENTRO_DO_PLANEJAMENTO_INTEGRAD O_DE_RECURSOS]; acesso em 08/03/2021.

RC: 99138

Access Link: https://www.nucleodoconhecimento.com.br/engineering-mechanicalengineering/integration-management 
MOLWUS, Jurbe Joseph. Stakeholder Management in Construction Projects: A Life Cycle Based Framework. PhD thesis in Construction Philosophy, presented to Heriot Watt University. Oct, 2014. Available in: [https://core.ac.uk/download/pdf/77035943.pdf]; access in march 8, 2021.

MONTES, Eduardo. Gerenciamento das partes interessadas: o que é e como fazer. 02 out 2020. Disponível em: https://escritoriodeprojetos.com.br/gerenciamentodas-partes-interessadas-do-projeto; acesso em 01/03/2021.

OLIVEIRA, Ricardo Rocha. Sistematização e a listagem de fatores que afetam a construtibilidade. [In]: Encontro Nacional de Engenharia de Produção - ENEGEP, 1995.

PINA, Jorge Henrique de Morais; CORRÊA, Victor Japiassú. Implementação De Usinas Fotovoltaicas Com Geração Compartilhada. Monografia [graduação] apresentada ao Curso de Engenharia Civil da Unievangélica. ANÁPOLIS, 2018. Disponível em: [http://repositorio.aee.edu.br/handle/aee/114]; acesso em 08/03/2021.

PINHO, João Tavares; GALDINO, Marco Antonio. Manual de engenharia para sistemas fotovoltaicos. 2014. CEPEL/CRESESB. Disponível em: [http://www.cresesb.cepel.br/publicacoes/download/Manual_de_Engenharia_FV_201 4.pdf]; acesso em 08/03/2021.

PMI-SP - PROJECT MANAGEMENT INSTITUTE São Paulo, Brasil. Certificação PMISP. 2020. Disponível em: [https://pmisp.org.br/pmi-sp/]; acesso em 08/03/2021.

PMI - PROJECT MANAGEMENT INSTITUTE. Um Guia do Conhecimento de Gerenciamento de Projetos. Guia PMBOK. 6 Edição. 2017. INC. Constrution Extension to the PMBOK® Guide. Pensilvania, USA. 2016.

RC: 99138 
. Um Guia do Conhecimento de Gerenciamento de Projetos. Guia

PMBOK. 5a. edição. 2013.

. Um Guia do Conhecimento de Gerenciamento de Projetos. Guia PMBOK. 4를 Edição. 2012

RABECHINI JR, Roque; PESSÔA, Marcelo Schneck de Paula. Um modelo estruturado de competências e maturidade em gerenciamento de projetos. Revista Produção, vol. 15, n. 1, p. 034-043, Jan./Abr. 2005. Disponível em: [https://www.scielo.br/pdf/prod/v15n1/n1a03.pdf]; acesso em em 08/03/2021.

SERVOS, Frederico Madeira De Ley. Os Estímulos Dos Usuários de Sistemas Fotovoltaicos Do Rio De Janeiro. Monografia [Graduação] em Administração de empresas apresentada ao Departamento de Administração do CENTRO DE CIÊNCIAS SOCIAIS (CCS) da Pontifícia Universidade Católica (PUC) do Rio de Janeiro. Rio de Janeiro, Dezembro de 2016. Disponível em: [https://www.maxwell.vrac.puc-rio.br/31009/31009.PDF]; acesso em 08/03/2021.

SIQUEIRA, Vera Aparecida Cordeiro; MENEZES, Bruno Anthony Gonçalves; OLIVEIRA, Altamir Fernandes de. Gerenciamento das Partes Interessadas: diagnóstico realizado com base no PMBOK® na Pró-Reitoria de Extensão e Cultura da UFVJM. Anais do VII SINGEP - São Paulo - SP - Brasil - 22 e 23/10/2018. Disponível em: [http://www.singep.org.br/7singep/resultado/179.pdf]; acesso em 08/03/2021.

SOUSA, Rodrigo Zanata Pereira de; BARBOSA, Fernanda Azevedo; CALDEIRA, Michael Vinícius Martins; STIVAL, Ângela Mendes. Gestão de projetos aplicada à construção civil. Revista Científica Multidisciplinar Núcleo do Conhecimento. Ano 05, Ed. 01, Vol. 01, pp. 14-30. Janeiro de 2020. ISSN: 2448-0959. Disponível em: [https://www.nucleodoconhecimento.com.br/engenharia-civil/gestao-de-projetos]; acesso em: 08/03/2021.

RC: 99138

Access Link: https://www.nucleodoconhecimento.com.br/engineering-mechanicalengineering/integration-management 
TAFAZZOLI, Mohammadsoroush; SHRESTHA, Pramen P. Investigating Causes of Delay in U.S. Construction Projects. 53rd ASC Annual International Conference Proceedings. Sept $2017 . \quad$ Disponível em: [https://www.researchgate.net/publication/326693706]; acesso em 08/03/2021.

XAVIER, Carlos Magno da S. Metodologia de Gerenciamento de Projetos. Beware $\begin{array}{llll}\text { Consultoria } & \text { Empresarial } & \text { Ltda. } & \text { Disponível }\end{array}$ em: [http://g2b.com.br/downloads/07_metodologia_gerenciamento_de_projetos_carl os_magno_da_silva_xavier_2012.pdf]; acesso em 08/03/2021.

[1] Post-Graduate Lato Sensu - MBA in Project Management - Fundação Getúlio Vargas (FGV); Bachelor's in mechanical engineering - Federal University of Pernambuco. ORCID: https://orcid.org/0000-0002-6506-9768

Posted: June, 2021.

Approved: September, 2021.

RC: 99138 